Final Technical Report

\title{
NATIONAL ALLIANCE FOR CLEAN ENERGY INCUBATORS NEW MEXICO CLEAN ENERGY INCUBATOR
}

\author{
Grant DE-F636-02G012037
}

\author{
Prepared for: \\ U. S. Department of Energy \\ Golden Field Office \\ 1617 Cole Boulevard \\ Golden, Colorado 80401 \\ Attention: Steven L. Scott, Contracting Specialist \\ Submitted by: \\ Suzanne S. Roberts \\ Program Manager \\ Technology Ventures Corporation \\ 1155 University Boulevard, SE \\ Albuquerque, New Mexico 87106 \\ www.techventures.org
}

This publication was prepared for the U. S. Department of Energy, Golden Field Office. The statements, findings, conclusions, recommendations, and other data in this report are solely those of the author(s) and do not necessarily reflect the views of the Department of Energy.

December 15, 2004

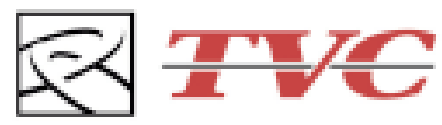

TECHNOLOGY VENTURES CORPORATION

Enabling Innovation - Accelerating Investment 


\section{CONTENTS}

$\underline{\text { Page }}$

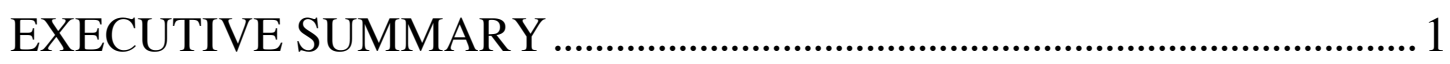

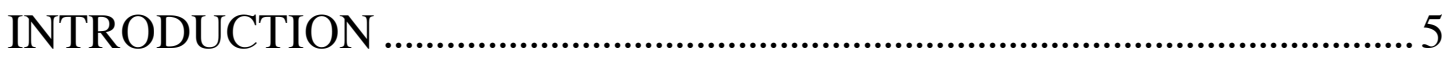

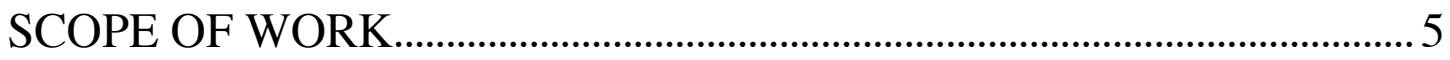

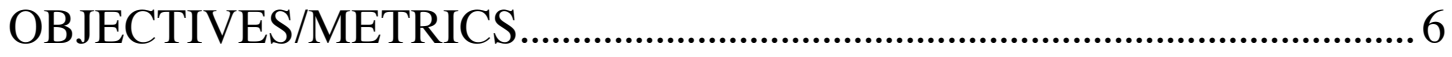

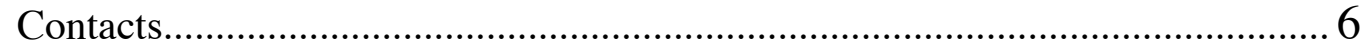

Value Added Services.................................................................................. 7

Establishing TVC and National Alliance Market Presence................................. 9

Support the NREL National Alliance of Clean Energy Business Incubators.... 11

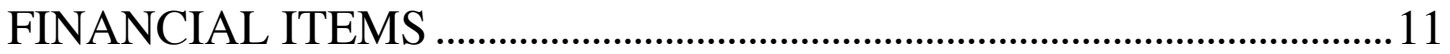

PROBLEM AREAS AND CORRECTIVE ACTION PLANS...................11

PLANS FOR THE NEXT PERIOD ........................................................11

APPENDIX A (TVC's Portfolio of Energy Clients as of 12/15/04)...............................12

APPENDIX B (Local Tech MesoFuel Bought by London Company)............................21

APPENDIX C (EnerPulse, Inc. Receives \$2.25M in Venture Capital)...........................25

APPENDIX D (No Longer Missing: NM Reappears on VC Reports/

Photovoltaic Cell Firm Advent Solar Receives \$400K - Series A) ..............................27

APPENDIX E (Solar Startup Shines/Advent Solar Wins National Award/

News from Bechtel) ..............................................................................................

APPENDIX F (Excerpts from Commercial Break).......................................................42

APPENDIX G (TVC Awards \$10,000 Roadrunner Grant to AFS Trinity Power)..........46

APPENDIX H (TVC is a Proud Partner of the Sustain Taos Initiative/

Technology Ventures Corporation: A Bridge Between Clean Energy

Entrepreneurs and Equity Investors)............................................................................48

APPENDIX I (HyTeP - The Hydrogen Technology Partnership)...................................52

APPENDIX J (Gov. Richardson Joins FPL Energy and PNM to Dedicate

World's Largest Wind Generation Facility) ..............................................................55 


\section{EXECUTIVE SUMMARY}

Technology Ventures Corporation (TVC) is one of 11 members of the National Alliance of Clean Energy Business Incubators dedicated to accelerating the growth and success of clean energy and energy efficiency companies through an array of business support services. The Alliance is a National Renewable Energy Laboratory (NREL) initiative with support from the U.S. Department of Energy.

During the course of TVC's period of performance under the Alliance initiative from September 2002 through September 2004, TVC met or exceeded its contractual obligations. Accomplishments are organized into four categories.

\section{OBJECTIVES AND METRICS}

TVC's contribution to the Alliance was significant over the two-year period of performance, as indicated in the table below.

\begin{tabular}{|l|}
\hline Company Clients in TVC's Incubator: 28 \\
\hline Graduate Companies: 7 \\
\hline Employees at Companies: 151 \\
\hline Capital Raised: $\$ 35,311,000$ \\
\hline Revenues Generated: $\$ 5,125,000$ \\
\hline State Money Raised: $\$ 520 \mathrm{~K}$ \\
\hline $\begin{array}{l}\text { Other private leveraged funds: } \$ 3.3 \mathrm{M} \text { from } \\
\text { Lockheed Martin Company, TVC's founder }\end{array}$ \\
\hline
\end{tabular}

TVC met or exceeded NREL program objectives and metrics, including advancing 13 new TVC clients to project status from its portfolio of energy candidates (Appendix A). Advancement to project status enables introductions to qualified equity investors. Five of the 12 new projects advanced by TVC have received equity funding totaling nearly $\$ 26,000,000$. Notable among these fundings is MesoFuels that was acquired by Intelligent Energy, a London-based fuel cell developer, for an estimated $\$ 10,000,000$. MesoFuels is expected to remain in Albuquerque (Appendix B).

- AFS Trinity

- Clear Skies Unlimited, Inc.

- Enerpulse: Received \$2,250, 000 in equity funding (Appendix C)

- FastDitch, Inc.

- H2 Onsite

- Jadoo Power: Received $\$ \$ 5 \mathrm{M}$ in equity funding

- MesoFuels: Received \$13, 700,000 in equity funding

- New Mexico Power Devices

- Redwood Rubber, LLC

- Solaria: Received $\$ 500,000$ in equity funding

- The Wind Turbine Company

- UltraCell: Received $\$ 4.5 \mathrm{M}$ in equity funding

- Weather Miser 
During the two-year period, TVC also assisted in facilitating business formations and accelerating investments for two TVC clients in its portfolio prior to the Alliance initiative: Advent Solar $(\$ 625 \mathrm{~K})$ and Surfect Technologies, Inc. $(\$ 5,135,000)$, Appendix D.

Additionally, TVC mentored 12 clients who were accepted to present their business opportunities to qualified investors at prestigious equity conferences, such as the 2003 and 2004 NREL Industry Growth Forums in Austin, TX, and Orlando, FL, and the annual 2003 and 2004 TVC Equity Capital Symposiums in San Francisco, CA, and Albuquerque, NM.

- Advent Solar

- AFS Trinity Power

- Clear Skies Unlimited, Inc.

- Enerpulse

- H2 Onsite

- MesoFuels

- Redwood Rubber, LLC

- Sacred Power

- Solaria

- Surfect

- The Wind Turbine Company

- Weather Miser

Significantly, Advent Solar took top honors at the 2003 forum by winning the National Clean Energy Venture Competition (Appendix E) valued at \$10,000.

\section{VALUE ADDED SERVICES}

Leveraging off its founder, Lockheed Martin Company, its partnership with the National Nuclear Security Administration, and the National Alliance of Clean Energy Incubators, TVC was able to offer its roster of energy technology clients a host of educational and networking opportunities including access to:

- Complimentary subscription to the TVC-published bimonthly TechComm: The National Journal of Technology Commercialization. Distributed to 10,000 readers, the June/July 2004 and August/September 2004 issues were devoted to the subject of energy and featured an article describing the Alliance as well as a perspective on commercializing clean energy companies co-written by Dr. Lawrence Murphy, who is manager of Enterprise Development Programs at NREL which include the Alliance initiative.

- $\quad$ TVC-published Commercial Break newsletter highlighting energy clients to TVC's network of investors and strategic partners (Appendix F).

- The TVC-sponsored Technology Executives Council bimonthly breakfast.

- The TVC-sponsored Center for Commercialization and Entrepreneurial 
Monthly Training.

- Access to professional business advisors, including experts in the SBA Small Business Innovation Research program, intellectual property, market research, and human resource development.

- Annual TVC New Mexico and California Equity Capital Symposiums:

The Solaria Corporation, Weather Miser, and Enerpulse were introduced to investors at the two TVC Equity Capital Symposiums held in Albuquerque, May 2003, and Livermore, CA, October 2003. In 2004, Advent Solar, The Wind Turbine Company, and Clear Skies Unlimited presented before investors at TVC symposiums in San Francisco and Albuquerque.

- NREL Industry Growth Forums: From over 100 applications submitted, seven TVC energy clients were selected to present at the $200316^{\text {th }}$ NREL Growth Forum in Austin, TX, with TVC client Advent Solar winning a national award valued at $\$ 10,000$. For the 2004 NREL Forum in Orlando, TVC qualified two companies to present and had a third selected as an alternate.

- Road Runner Grant: TVC awarded a \$10K Road Runner grant to AFS Trinity Power Corporation in November 2003. The company was among the TVC clients presenting at the 2003 NREL Forum and the 2004 TVC California Equity Symposium (Appendix G).

\section{ESTABLISHING TVC ALLIANCE MARKET PRESENCE}

TVC participated in the following outreach activities to promote the Alliance:

- Mentor: TVC 2003 and 2004 Equity Capital Symposiums in New Mexico and California

- Mentor: The 2003 and 2004 NREL Investor Growth Forums in Texas and Florida

- Participant: The $200215^{\text {th }}$ NREL Investor Growth Forum, Albany, New York

- Contributing author and sponsor for the Taos Green Guide for Sustainable Living (Appendix H)

- Organizing Committee Member, New Mexico Hydrogen Technology Partnership (Appendix I)

- Member, Implementation Team, New Mexico First Town Hall on Energy

- Exhibitor, Sustainable Energy Day

- Exhibitor, NM State Fair Renewable Energy Day

- Speaker, BioEnegy to Dollars Conference

- Speaker and Exhibitor, Hydrogen Technology Partnership at the New Mexico Legislature

- Speaker, "Emerging Technologies in Energy Efficiency—Summit 2004," hosted in San Francisco, CA, by the American Council for an Energy Efficient Economy, Pacific Gas and Electric Company, Sempra Energy, Southern California Edison, and the California Energy Commission

- Speaker and Participant, New Mexico Sustainable Energy Collaborative Council

- Participant, Biomass Working Group

- Participant, Solar Energy Technology Systems Symposium 
- Participant, Public Service Company of New Mexico Wind Center Dedication (Appendix J)

- Participant, New Mexico Wind Energy Conference

- Participant, U.S. Senatorial Field Hearing on Advanced Energy Technology

- Participant, Wind Turbine Blade Workshop

- Participant, North American Energy Summit

- Participant, Identifying Technologies to Improve Regional Water Stewardship

- Established relationships with key members of Sandia National Laboratory Department 6000, Energy, Information, and Infrastructure Surety

\section{SUPPORT FOR THE NREL NATIONAL ALLIANCE OF CLEAR ENERGY INCUBATORS}

TVC participated in all meetings and conferences of the Alliance and referred clients as appropriate to other Alliance members. TVC's most significant achievement in this area was to qualify seven of its clients to present at the $200316^{\text {th }}$ NREL Industry Growth Forum in Austin, Texas. More than 100 applications were received; 34 were accepted; 10 of those accepted were from clients of the Alliance members; of the 10 Alliance clients, seven were TVC clients. The seven clients that presented were Advent Solar, AFS Trinity Power Corporation, MesoFuels, Sacred Power Corporation, The Solaria Corporation, Surfect Technologies, Inc., and Weather Miser, Inc.

Crowning the outstanding participation of TVC clients at the forum was the venture capital community recognition of Advent Solar as the best presenter in the field.

In 2004, TVC two clients were accepted to present at the Forum in Orlando: Redwood Rubber, LLC, and The Wind Turbine Company. Zia Power, also a TVC client, was invited to participate as an alternate.

TVC considers its accomplishments under its first two years of the the Alliance initiative as notable; TVC expects prospects for 2005 to be equally robust. 


\section{INTRODUCTION}

The National Alliance for Clean Energy Incubators was established by the National Renewable Energy Laboratory (NREL) to develop an emerging network of business incubators for entrepreneurs specializing in clean energy enterprises. The Alliance provides a broad range of business services to entrepreneurs in specific geographic locales across the U.S. and in diverse clean energy technology areas such as fuel cells, alternative fuels, power generation, and renewables, to name a few.

Technology Ventures Corporation (TVC) participates in the Alliance from its corporate offices in Albuquerque, NM, and from its sites in Northern and Southern New Mexico, California, and Nevada. TVC is one of the 11 current Alliance partners located throughout the USA.

\section{SCOPE OF WORK}

To accomplish the objective of the project, TVC assesses the technology commercialization demands of the private sector, provides technology and business maturation assistance, and serves as a cost-free facilitator between the clean energy technology entrepreneur and investment from the private sector. TVC's clean energy technology commercialization service is headquartered in Albuquerque, New Mexico, and provided in most of the counties of New Mexico by TVC. Experience has shown that TVC can significantly leverage other federal and private sector resources. The focus is all of New Mexico, but the counties of Los Alamos and Santa Fe in the north; Sandoval, Valencia, Bernalillo and Torrance in the central; and Socorro and Doña Anna in the south receive special emphasis. Additionally, TVC supports the Alliance through clean energy commercialization services offered from its sites in Las Vegas, Nevada and Livermore, California.

Historically, the commercialization success rate for clean energy technology coming from small, start-up or early stage businesses is low relative to the investment of federal dollars. In previous efforts made to engage the clean energy technology companies with private equity funding, TVC has found that motivating the key decision makers to participate in the commercialization process is difficult and requires more time to accomplish than in other sectors. However, significant lessons have been learned, which should lead to significant clean energy technology entering the commercial market, producing major positive economic impact.

Although commercializing clean energy technology is a formidable task, methodologies have been put in place by TVC that greatly improve the chances of successful commercialization events. TVC has applied a more aggressive model for commercialization using a strong business case/equity capital approach. 
Implementation of the model provides that assistance is rendered in some or all of the following areas:

- Identify the technologies and enterprises applicable to commercialization;

- Develop business cases around the technologies;

- Assist in market research and analysis;

- Critique, review and edit business plans;

- Assess and recommend growth and market penetration strategies;

- Evaluate organization and management structures;

- Make introduction of technology commercialization business cases to private equity capital sources.

Carefully guiding clean energy technology into the commercial market is key to the process. TVC has extensive experience in assisting technology developers and entrepreneurs through the process. TVC has been able to bridge the chasm between raw technology and the marketplace.

After maturation of the business case, TVC arranges introductions of the commercial opportunities to private capital sources such as venture capital firms and investment arms of corporations from across the U.S.

Because of TVC's previous experience and broad relationships with private industry and investors, this project benefits from a skill set that leads to investment in clean energy start-up companies historically underserved by the investment capital community. Because of the broad reach of TVC, the participating investors and corporations extend nationally. This same span of investor, private industry and energy community relationships provides recognition for $\mathrm{DOE}$, and the services offered demonstrate NREL's creativity in developing new ways to effectively provide business economic development through clean energy technology industries.

\section{OBJECTIVES/METRICS}

\section{$>$ CONTACTS}

\begin{tabular}{|c|c|c|c|c|}
\hline $\begin{array}{c}\text { Total } \\
\text { Contacts }\end{array}$ & Possible & Inquiry & Opportunity & Projects \\
\hline 80 & 74 & 13 & 7 & 13 \\
\hline
\end{tabular}

All contacts made by the TVC NREL operatives are counted in the "Total Contacts" category except clearly incidental contacts with venture capitalists, bankers, and other professional services providers (lawyers, accountants, etc.). The "incidental" are important to our success, but they are not potential clients for the NREL project. If the 
initial contact indicates that these people/companies meet the NREL client status, they move to the "Possible" status. Our expectation at this point is that the "Possible" leads could become projects and ultimately "successes."

The TVC model moves a possible prospect to the contact or "Inquiry" stage. The next stage is the preparation of a business case or "Opportunity" stage after initial interviews and meetings with the entrepreneurial entity and agreement by the entrepreneur to create a business plan in accordance with TVC's specifications. An entity moves from Opportunity to full Client or "Project" status after a business plan has been reviewed and approved through the "screening process" by the TVC screening committee. The screening committee is made up of all of the TVC and NREL project managers and TVC's Director of Administration. An "Opportunity" becomes a "Project" when the business case, in the form of a business plan, successfully passes or is approved by the screening committee. The project is then positioned for introduction as a possible business meriting equity funding.

\section{$\gg$ VALUE ADDED SERVICES}

TVC, in its normal course of business, provides the value-added services committed to in the Statement of Work. Mentoring and counseling entrepreneurs and developing an investor network are principal activities.

TVC garnered nationwide recognition for the Alliance through articles published in TECHCOMM: The National Journal of Technology Commercialization. TECHCOMM is a new bimonthly magazine published by TVC in partnership with the National Nuclear Security Administration (NNSA). It reports on new technologies, entrepreneurial activity, topics of interest to investors, activity at NNSA laboratories, and issues concerning technology transfer. Distributed to 10,000 subscribers, the June/July and August/September 2004 issues were dedicated to energy matters, including articles about the Alliance and one focusing on energy commercialization coauthored by Dr. Lawrence Murphy, manager of the Alliance and other Enterprise Development Programs at NREL. For archives of the articles, visit www.techcommjournal.com.

TVC publishes the monthly Commercial Break newsletter distributed to over 1000 readers, the majority of whom are venture capitalists. Several issues in 2003 and 2004 spotlighted TVC energy companies.

Additionally, TVC has established a number of programs that accelerate the ability of entrepreneurs to develop successful clean energy companies, services and products. One program is the CCET training program (Center for Commercialization and Entrepreneurial Training). This program trains entrepreneurs in the rudiments of business case and business plan development through monthly training sessions taught by TVC and affiliates. The training also provides guidance on how to access private equity funding for their technology. 
Should an entrepreneurial business case be adopted by TVC into "client" or "project" status, the business case may be invited to participate in the two TVC Equity Capital Symposiums in which the business case is formally presented to investor groups. Entering its twelfth year, The TVC New Mexico Equity Capital Symposium (NMECS) is held in May of every year in Albuquerque. Now two years old, The TVC California Equity Capital Symposium (CAECS) is held annually during September in San Francisco. Historically, 30 percent of the presenters at TVC's symposiums have received equity funding.

Similarly, TVC encourages and helps energy clients qualify for the annual NREL Equity Growth Forum as another excellent opportunity to inform investors about their business opportunities. Held in various locations across the country, the NREL Forum has been in operation since 1995. The table below captures the participation of TVC's energy clients in the various symposiums and forums over the last two years.

While TVC works around the year to introduce qualified entrepreneurs to sources of capital, the TVC New Mexico and California Symposiums and the NREL Growth Forums present ideal opportunities to showcase promising energy investments.

\begin{tabular}{|c|c|c|c|c|c|c|c|}
\hline Presenter & $\begin{array}{l}2003 \\
\text { NMECS }\end{array}$ & $\begin{array}{l}2003 \\
\text { CAECS }\end{array}$ & $\begin{array}{l}2003 \text { NREL } \\
\text { Forum }\end{array}$ & $\begin{array}{l}2004 \\
\text { NMECS }\end{array}$ & $\begin{array}{l}2004 \\
\text { CAECS }\end{array}$ & $\begin{array}{l}2004 \text { NREL } \\
\text { Forum }\end{array}$ & $\begin{array}{l}\text { Capital } \\
\text { Raised }\end{array}$ \\
\hline Advent Solar & & & & & & & $\$ 625 \mathrm{~K}$ \\
\hline $\begin{array}{l}\text { AFS Trinity } \\
\text { Power }\end{array}$ & & & & & & & $\$ 59 \mathrm{~K}$ \\
\hline \multicolumn{8}{|l|}{$\begin{array}{l}\text { Clear Skies } \\
\text { Unlimited }\end{array}$} \\
\hline Enerpulse & & & & & & & $\$ 2.25 \mathrm{M}$ \\
\hline \multicolumn{8}{|l|}{ H2 Onsite } \\
\hline MesoFuels & & & & & & & $\$ 13.7 \mathrm{M}$ \\
\hline \multicolumn{8}{|l|}{$\begin{array}{l}\text { Redwood } \\
\text { Rubber }\end{array}$} \\
\hline $\begin{array}{l}\text { Sacred } \\
\text { Power }\end{array}$ & & & & & & & $\$ 825 \mathrm{~K}$ \\
\hline Solaria & & & & & & & $\$ 500 \mathrm{~K}$ \\
\hline Surfect & & & & & & & $\$ 5.65 \mathrm{M}$ \\
\hline $\begin{array}{l}\text { Wind Turbine } \\
\text { Company }\end{array}$ & & & & & & & $\$ 800 \mathrm{~K}$ \\
\hline Weathermiser & & & & & & & \\
\hline
\end{tabular}

Networking opportunities are provided through the training sessions and the bi-monthly TEC breakfasts sponsored by TVC. This is a venue for founders/presidents of entrepreneurial companies to network and compare notes about business issues.

TVC maintains a roster of service providers, including law, accounting, and marketing firms. TVC may arrange for consultation between these service providers, acting in the role of advisor, and entrepreneurs. Normally the initial consultations are pro bono. 
Final Technical Report

These entrepreneurs selected for the ECS may receive up to four months of pro bono consultation.

\section{$\gg$ ESTABLISHING TVC AND NATIONAL ALLIANCE MARKET PRESENCE}

One of the objectives of the project is to advance the market presence of TVC and the National Alliance through participation in energy-related activities. TVC made significant progress in this area as shown by the following examples.

TVC was a contributing author and sponsor of the first annual Taos Green Guide for Sustainable Living. Thirty thousand copies of the 84-page publication were circulated in Taos County in late 2004. The title of the TVC article was "Technology Ventures Corporation: A Bridge between Clean Energy Entrepreneurs and Equity Investors."

TVC became an organizing committee member of the New Mexico Hydrogen Technology Partnership (HyTeP). Established in 2003, HyTeP is an alliance representing industry, business, research laboratories, universities, and government working together to enhance the economic development of New Mexico and the nation through a cooperative focus on hydrogen and fuel cell research, development, demonstration, and commercialization. In February 2004, HyTeP invited TVC and other member organizations to introduce their role in HyTeP to legislators in the Santa Fe State Capitol Rotunda.

TVC was an invited speaker at the Biomass-to-Busine $\$$ Conference held in Albuquerque during March 2004. The objective of the conference was to advance the biomass industry in New Mexico. TVC addressed options for financing bioenergy projects, with a focus on private equity investors.

In April 2004, TVC participated as a technology commercialization panelist in the North American Energy Summit hosted in Albuquerque and led by Governor Bill Richardson, Chairman of the Western Governors' Association. Participants included energy experts from the U.S., Canada, and Mexico. MesoFuel, a TVC client recently acquired by London-based Intelligent Energy, exhibited at the summit. The company displayed its compact product that generates smaller quantities of hydrogen more efficiently, less expensively, and without most of the pollutants associated with hydrogen production from fossil fuels.

TVC was an invited speaker at the Emerging Technologies for Energy Efficiency October 2004 Summit hosted in San Francisco, CA, by the American Council for an Energy Efficient Economy, Pacific Gas and Electric Company, Sempra Energy, Southern California Edison, and the California Energy Commission. TVC provided information, insights, and strategies to assist entrepreneurial researchers, developers, and manufacturers understand the financial marketplace for launching and scaling new energy efficiency technology enterprises. Addressing 50 attendees, TVC shared the podium with Nth Power, a premier venture capital fund in the clean energy space. 
TVC participated in the First Town Hall on New Mexico's Energy, Economics, and Environment held in Carlsbad, New Mexico in November 2002. Subsequently, TVC served through October 2003 on the implementation team organized to execute the recommendations resulting from the Town Hall. The Town Hall is policy by consensus format. New Mexico First is a non-partisan, non-profit entity founded jointly by Senators Pete Domenici (R-NM) and Jeff Bingaman (D-NM).

On February 21, 2003, TVC attended, displayed and promoted our affiliation with the NREL Clean Energy Incubator Alliance, at the 2003 Sustainable Energy Day at the New Mexico legislature in Santa Fe. Registered attendees included private industry participants, including entrepreneurs with clean energy technologies, industry coalitions, utilities, national laboratories, universities, and state and federal agencies with an interest in sustainable energy technologies. It presented TVC with the opportunity to communicate its involvement in the renewable energy space and to engage with potential clients regarding equity capital funding and the services TVC provides in linking entrepreneurs with investors. It also allowed TVC the opportunity to educate the various institutional players on how TVC can be of assistance to their clean energy clients.

On September 19, 2003, TVC was an exhibitor at the New Mexico State Fair during a day-long exploration and celebration of renewable energy. The event was sponsored by New Mexico First, the New Mexico Economic Development Administration, and the New Mexico Department of Energy and Minerals.

TVC was an invited speaker at the New Mexico Sustainable Energy Collaborative Council in October 2002 and subsequently began attendance at monthly meetings there as well as with the Biomass Working Group.

TVC was a participant at the Solar Energy Technology Systems Symposium held October 15-17, 2003, in Albuquerque, and sponsored by Sandia National Laboratories. A highlight of the symposium was a breakout session on bringing solar energy technologies to markets.

TVC participated in the Public Service Company of New Mexico (PNM) Wind Center Dedication held in House, New Mexico, on October 1, 2003, approximately 200 miles east of Albuquerque. A joint project between PNM and FPL Energy, the wind center is the third largest wind generation facility in the world, and will generate $204 \mathrm{MW}$ of electricity, enough to supply 94,000 homes. FPL energy owns and operates the center's 136 wind turbines; PNM purchases all the power.

TVC participated in the Wind Energy Conference held October 21, 2003 in Albuquerque.

TVC also attended the Senatorial Field Hearing on Advanced Energy Technology conducted by Senator Jeff Bingaman in October 2002.

TVC participated in the evaluation of business plans that were screened for inclusion in the New Mexico and California Equity Capital Symposiums (ECS) held in 2003 and 
2004. Additionally, TVC developed entrepreneurs to present at the 2003 and 2004 NREL Industry Growth Forums. In total, TVC prepared 12 entrepreneurs to present formal presentations and business plans to investors.

Finally, TVC made progress in establishing relationships with key members of Sandia National Laboratory organization 6000, Energy, Information, and Infrastructure Surety. Contacts within the department are important for a number of reasons, including assistance from the department in identifying potential clean energy entrepreneurs and providing top-level analyses of emerging energy technologies.

\section{$>$ SUPPORT FOR THE NREL NATIONAL ALLIANCE OF CLEAN ENERGY BUSINESS INCUBATORS}

TVC attended the National Alliance's Industry Growth Forums in Albany, New York in October 2002, Austin, Texas in 2003, and Orlando, Florida in 2004. TVC recruited and qualified seven clients who were selected to present in the 2003 forum. For the 2004 forum, TVC recruited and qualified two clients who were selected to present, with a third invited to attend as an alternate. TVC also participated in the annual NREL Clean Energy Alliance meetings in Golden, CO, in February 2003 and May 2004. These activities are requirements of the NREL contract with TVC. TVC also provided input for the Alliance annual report, periodic surveys, and collateral material.

\section{FINANCIAL ITEMS}

The items relating to the financial items are discussed as a part of the quarterly invoice which was submitted as a separate transmission to NREL on October 6, 2004. There are no exceptional items or problem areas involving grant financials.

\section{PROBLEM AREAS AND CORRECTIVE ACTION PLANS}

There are no problem areas or other open corrective action plans associated with the grant.

\section{PLANS FOR THE NEXT PERIOD}

Plans for the next year include TVC's participation in the annual Alliance meeting to be held in Golden, Colorado and the $18^{\text {th }}$ NREL Industry Growth Forum. 
Final Technical Report

APPENDIX A 


\section{National Alliance of Clean Energy Business Incubators Metrics Survey}

\section{Incubator: Technology Ventures Corporation}

"City, State:" "Albuquerque, New Mexico"

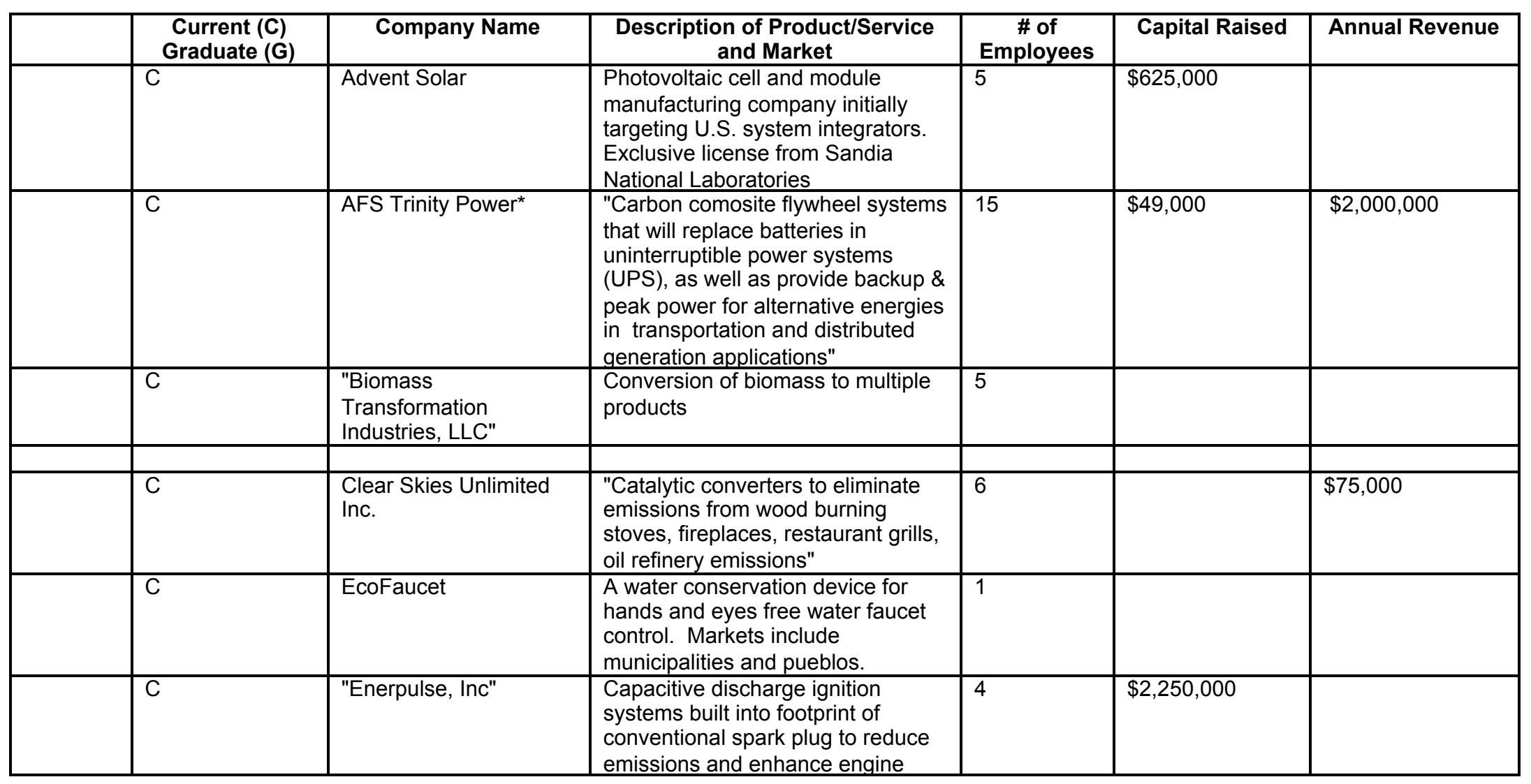


Final Technical Report

\begin{tabular}{|c|c|c|c|c|c|c|}
\hline & $\begin{array}{l}\text { Current (C) } \\
\text { Graduate (G) }\end{array}$ & Company Name & $\begin{array}{c}\text { Description of Product/Service } \\
\text { and Market }\end{array}$ & $\begin{array}{c}\text { \# of } \\
\text { Employees }\end{array}$ & Capital Raised & Annual Revenue \\
\hline & & & performance & & & \\
\hline & $\mathrm{C}$ & Fast Ditch & $\begin{array}{l}\text { "Irrigation and erosion control } \\
\text { ditches made from recyclable } \\
\text { polyethylene lining that is cheaper, } \\
\text { less damaging to install, and } \\
\text { requires less maintenance" }\end{array}$ & 5 & & \\
\hline & $\mathrm{C}$ & Generate Technologies & $\begin{array}{l}\text { Process to apply signal processing } \\
\text { to increase energy efficiency of } \\
\text { power transmission and generation }\end{array}$ & 5 & $\$ 620,000$ & \\
\hline & $\mathrm{C}$ & Global Technologies Inc & Nuclear power cells & 11 & & \\
\hline & $\mathrm{G}$ & "Gratings, Inc. ${ }^{* * "}$ & $\begin{array}{l}\text { Microfabrication technique to } \\
\text { resolve manufacturing problems } \\
\text { related to thin film photovoltaics. } \\
\text { Target market is photvoltaic system } \\
\text { manufacturers such as BP Solar } \\
\text { and Siemens }\end{array}$ & 6 & $\$ 700,000$ & \\
\hline & C & H2onsite & $\begin{array}{l}\text { "Steam electrolysis technology, } \\
\text { powered by methanol, used to } \\
\text { generate high purity hydrogen used } \\
\text { for semiconductor fab applications } \\
\text { and, ultimately, distributed } \\
\text { Hydrogen refueling for fuel cell } \\
\text { powered vehicles. " }\end{array}$ & 2 & & \\
\hline & $\mathrm{G}$ & $\begin{array}{l}\text { International } \\
\text { Combustion } \\
\text { Enhancement } \\
\text { Organization }\end{array}$ & $\begin{array}{l}\text { "Device to reduce hazardous air } \\
\text { emissions in all combustion } \\
\text { processes; target markets include } \\
\text { automotive OEMS, automotive } \\
\text { companies, electronics companies" }\end{array}$ & 2 & & \\
\hline & G & Jadoo Power Systems & $\begin{array}{l}\text { Fuel Cell batteries for remote } \\
\text { surveillance systems and network } \\
\text { broadcast camera. }\end{array}$ & 19 & $\$ 5,000,000$ & \\
\hline & $\mathrm{C}$ & Las Vegas Compost & Conversion of manure to compost & 2 & & \\
\hline & $\mathrm{C}$ & "MesoFuels, Inc." & $\begin{array}{l}\text { "Hydrogen generators for portable, } \\
\text { auxiliary, and stationary power } \\
\text { used by military, commercial, and } \\
\text { residential customers" }\end{array}$ & 11 & $\$ 13,700,000$ & $\$ 1,100,000$ \\
\hline & C & $\begin{array}{l}\text { New Mexico Power } \\
\text { Devices }\end{array}$ & $\begin{array}{l}\text { Gallium nitride diodes for increased } \\
\text { energy efficiency }\end{array}$ & & & \\
\hline
\end{tabular}




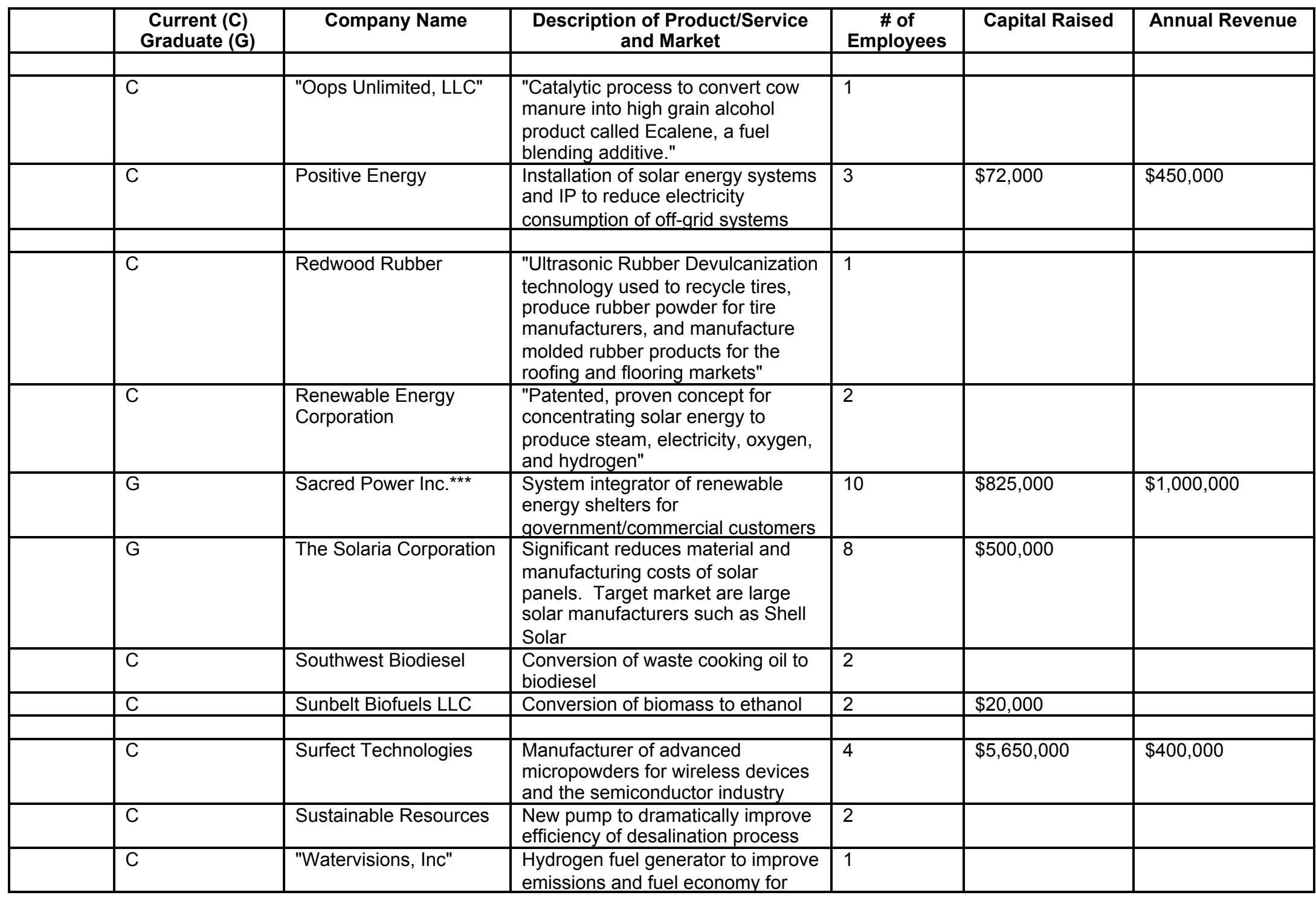




\begin{tabular}{|c|c|c|c|c|c|c|}
\hline & $\begin{array}{l}\text { Current (C) } \\
\text { Graduate (G) }\end{array}$ & Company Name & $\begin{array}{l}\text { Description of Product/Service } \\
\text { and Market }\end{array}$ & $\begin{array}{c}\text { \# of } \\
\text { Employees }\end{array}$ & Capital Raised & Annual Revenue \\
\hline & & & gas and diesel engines & & & \\
\hline & $C$ & Weathermiser Inc. & $\begin{array}{l}\text { Irrigation control device to } \\
\text { dramatically conserve water; } \\
\text { addresses the smart weather } \\
\text { sensor market forecasted to grow } \\
\text { to } \$ 3.87 \mathrm{~B} \text { by } 2006\end{array}$ & 2 & & $\$ 100,000$ \\
\hline & $\mathrm{C}$ & $\begin{array}{l}\text { Wind Turbine } \\
\text { Company**** }\end{array}$ & $\begin{array}{l}\text { New 2-blade wind turbine that } \\
\text { costs less to manufacture and } \\
\text { produces as much or more } \\
\text { electricity than turbines currently } \\
\text { used. }\end{array}$ & 12 & $\$ 800,000$ & \\
\hline & G & Wind Ergy & $\begin{array}{l}\text { "Low wind speed, high power } \\
\text { output wind turbine" }\end{array}$ & 1 & & \\
\hline & G & UltraCell & $\begin{array}{l}\text { Methanol powered micro-fuel cell } \\
\text { with MEMs reformer for portable } \\
\text { electronics }\end{array}$ & 5 & "\$4,500,000 " & \\
\hline & $C$ & Xtra Energy & $\begin{array}{l}\text { Direct mehanol fuel cell stacks for } \\
\text { portable microelectronic } \\
\text { applications }\end{array}$ & 1 & & \\
\hline & C & "Zia Power, Inc." & $\begin{array}{l}\text { "Solar wafer, cell, and module } \\
\text { manufacturing company" }\end{array}$ & & & \\
\hline & 26 & Current & & $\overline{99}$ & $\$ 23,786,000$ & $\$ 4,125,000$ \\
\hline & 7 & Graduate & & 52 & $\$ 11,525,000$ & $\$ 1,000,000$ \\
\hline & & & & 0 & & \$- \\
\hline Total & 33 & & & 151 & $\$ 35,311,000$ & $\$ 5,125,000$ \\
\hline 2) & $\begin{array}{l}\text { State money } \\
\text { leveraged }\end{array}$ & & & & & \\
\hline & Amount & Source & & & & \\
\hline & & & & & & \\
\hline & "\$20,000 " & $\begin{array}{l}\text { Grant awarded to } \\
\text { Sunbelt Biofuels from } \\
\text { State of New Mexico }\end{array}$ & & & & \\
\hline & $\$ 500,000$ & $\begin{array}{l}\text { To Mesofuels via } \\
\text { Murphree Ventures and } \\
\text { NM State Investment }\end{array}$ & & & & \\
\hline
\end{tabular}




\begin{tabular}{|c|c|c|c|c|c|c|}
\hline & $\begin{array}{c}\text { Current (C) } \\
\text { Graduate (G) }\end{array}$ & Company Name & $\begin{array}{c}\begin{array}{c}\text { Description of Product/Service } \\
\text { and Market }\end{array} \\
\end{array}$ & $\begin{array}{c}\text { \# of } \\
\text { Employees }\end{array}$ & Capital Raised & Annual Revenue \\
\hline & & Council & & & & \\
\hline Total & " \$520,000 " & & & & & \\
\hline & & & & & & \\
\hline \multirow[t]{4}{*}{ 3) } & $\begin{array}{l}\text { Other leveraged } \\
\text { funds }\end{array}$ & & & & & \\
\hline & Amount & Source & & & & \\
\hline & "\$3,300,000 " & $\begin{array}{l}\text { Lockheed Martin } \\
\text { Company (since joining } \\
\text { Alliance) }\end{array}$ & & & & \\
\hline & " \$10,000 " & $\begin{array}{l}\text { Awarded by Technology } \\
\text { Ventures Corporation to } \\
\text { AFS Trinity Power } \\
\text { Corporation for } \\
\text { significant progress in } \\
\text { developing its } \\
\text { uninterruptible power } \\
\text { supply as a } \\
\text { replacement for lead- } \\
\text { acid batteries. }\end{array}$ & & & & \\
\hline Total & "\$3,310.000" & & & & & \\
\hline & & & & & & \\
\hline \multirow[t]{4}{*}{ 4) } & Partnerships & & & & & \\
\hline & Partner Name & $\begin{array}{l}\text { Description of } \\
\text { Relationship }\end{array}$ & & & & \\
\hline & $\begin{array}{l}\text { Lockheed Martin } \\
\text { Company }\end{array}$ & $\begin{array}{l}\text { Founder and among the } \\
\text { funders of Technology } \\
\text { Ventures Corporation }\end{array}$ & & & & \\
\hline & $\begin{array}{l}\text { "National Nuclear } \\
\text { Security } \\
\text { Administration } \\
\text { funds TVC under } \\
\text { a contract to } \\
\text { develop and } \\
\text { expand its } \\
\text { technology } \\
\text { commercializatio } \\
n \text { model in NM, }\end{array}$ & & & & & \\
\hline
\end{tabular}




\begin{tabular}{|c|c|c|c|c|c|c|}
\hline & $\begin{array}{c}\text { Current (C) } \\
\text { Graduate (G) }\end{array}$ & Company Name & $\begin{array}{l}\text { Description of Product/Service } \\
\text { and Market }\end{array}$ & $\begin{array}{c}\text { \# of } \\
\text { Employees }\end{array}$ & Capital Raised & Annual Revenue \\
\hline & $\mathrm{NV}$, and $\mathrm{CA}^{\prime \prime}$ & & & & & \\
\hline Total & 2 & & & & & \\
\hline & & & & & & \\
\hline 5) & $\begin{array}{l}\text { Technologies } \\
\text { commercialized } \\
\end{array}$ & & & & & \\
\hline Total & 0 & & & & & \\
\hline & & & & & & \\
\hline 6) & Awards & & & & & \\
\hline & Name of Award & Description of Award & $\begin{array}{l}\text { Recipient (Incubator or Company } \\
\text { Name) }\end{array}$ & & & \\
\hline & $\begin{array}{l}\text { "First Place, } \\
\text { Business } \\
\text { Facilities } \\
\text { Magazine " }\end{array}$ & $\begin{array}{l}\text { Selected for Economic } \\
\text { Development } \\
\text { Achievements }\end{array}$ & Technology Ventures Corporation & & & \\
\hline & $\begin{array}{l}\text { "Award of } \\
\text { Excellence, } \\
\text { Association of } \\
\text { University } \\
\text { Related } \\
\text { Research Parks } \\
\text { " }\end{array}$ & $\begin{array}{l}\text { Identified as a National } \\
\text { Model in technology } \\
\text { commercialization }\end{array}$ & Technology Ventures Corporation & & & \\
\hline & $\begin{array}{l}\text { "Vision Award, } \\
\text { Small Business } \\
\text { Administration" }\end{array}$ & $\begin{array}{l}\text { Recognized as a } \\
\text { National model for } \\
\text { venture and seed } \\
\text { capital development }\end{array}$ & Technology Ventures Corporation & & & \\
\hline & $\begin{array}{l}\text { "Tibbetts Award, } \\
\text { Small Business } \\
\text { Administration" }\end{array}$ & $\begin{array}{l}\text { Deemed a model of } \\
\text { excellence by the SBA's } \\
\text { Small Business } \\
\text { Innovation Research } \\
\text { Program }\end{array}$ & Technology Ventures Corporation & & & \\
\hline & $\begin{array}{l}\text { Best Native } \\
\text { American Owned } \\
\text { Business }\end{array}$ & $\begin{array}{l}\text { Selected Among the } \\
\text { Top } 25 \text { in New Mexico }\end{array}$ & Sacred Power Corporation & & & \\
\hline & $\begin{array}{l}\text { "American Indian } \\
\text { Business } \\
\text { Association, }\end{array}$ & $\begin{array}{l}\text { Certificate of } \\
\text { Appreciation }\end{array}$ & Sacred Power Corporation & & & \\
\hline
\end{tabular}


Final Technical Report

\begin{tabular}{|c|c|c|c|c|c|c|}
\hline & $\begin{array}{c}\text { Current (C) } \\
\text { Graduate (G) }\end{array}$ & Company Name & $\begin{array}{l}\text { Description of Product/Service } \\
\text { and Market }\end{array}$ & $\begin{array}{c}\text { \# of } \\
\text { Employees }\end{array}$ & Capital Raised & Annual Revenue \\
\hline & $\begin{array}{l}\text { University of New } \\
\text { Mexico Adnerson } \\
\text { School of } \\
\text { Business, } \\
\text { Turquoise Level" }\end{array}$ & & & & & \\
\hline & $\begin{array}{l}\text { "The Scientific } \\
\text { American } 50 \\
\text { Award, Energy } \\
\text { Category " }\end{array}$ & $\begin{array}{l}\text { Vice President of } \\
\text { Engineering recognized } \\
\text { for the design of new } \\
\text { wind turbines that are } \\
\text { more efficient and } \\
\text { produce more power }\end{array}$ & The Wind Turbine Co. & & & \\
\hline & $\begin{array}{l}2003 \text { National } \\
\text { Clean Energy } \\
\text { Venture } \\
\text { Competition }\end{array}$ & $\begin{array}{l}\text { "Awarded by } \\
\text { competition sponsor } \\
\text { Bechtel Corporation at } \\
16 \text { th Natiional } \\
\text { Renewable Energy } \\
\text { Laboratory Growth } \\
\text { Forum for best } \\
\text { entrepreneurial } \\
\text { presentation of } \\
\text { business case. Award } \\
\text { comprised } \$ 7,000 \text { in } \\
\text { cash and } \$ 3,000 \text { in } \\
\text { services." }\end{array}$ & Advent Solar, Inc. & & & \\
\hline Total & 7 & & & & & \\
\hline & & & & & & \\
\hline & $\begin{array}{l}"{ }^{\prime *} \text { AFS Trinity } \\
\text { Received } \\
\$ 49,000 \text { STTR } \\
\text { Navy Award } \\
\text { (referred by } \\
\text { TVC)" }\end{array}$ & & & & & \\
\hline & $\begin{array}{l}" * * \text { Gratings } \\
\text { Received } \\
\$ 700,000 \text { in } \\
\text { Small Business } \\
\text { Innovation } \\
\text { Research }\end{array}$ & & & & & \\
\hline
\end{tabular}


Final Technical Report

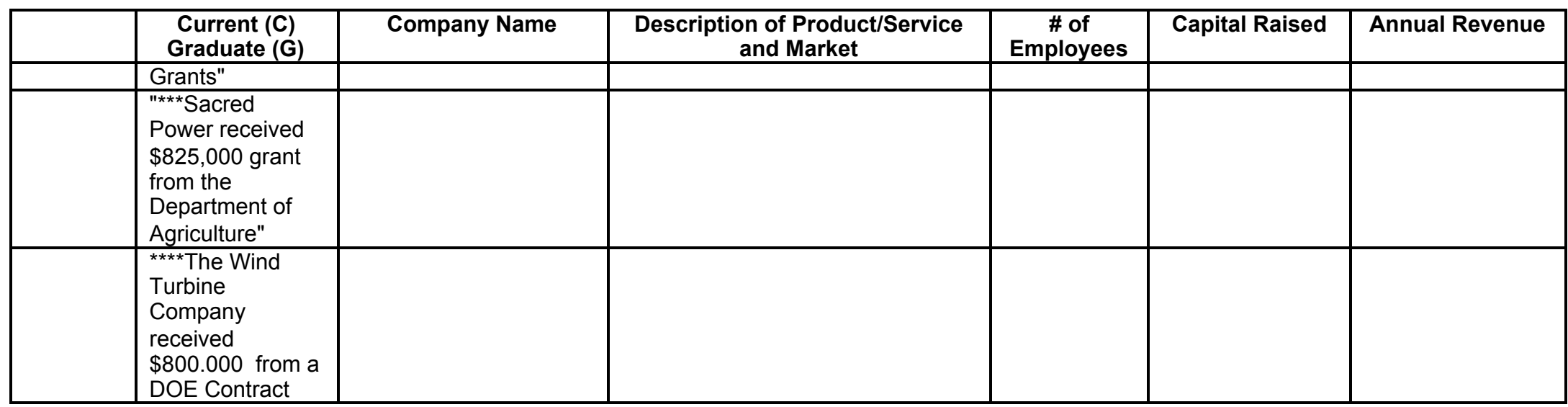


Final Technical Report

APPENDIX B 
Thursday, May 20, 2004

Local Tech MesoFuel Bought by London Company

By Andrew Webb

Journal Staff Writer

A fuel cell is nothing without the fuel. That is apparently what a London-based fuel cell developer, Intelligent Energy, was thinking when it sought a key component right here in Albuquerque. Intelligent Energy has acquired MesoFuel, which makes devices that provide the fuel, according to documents it filed pursuant to its application to trade on the London Stock Exchange.

Sherman McCorkle, of Technology Ventures Corp., which two years ago helped MesoFuel seek startup funding, confirmed this week that MesoFuel has been sold. He estimated the value of the sale, which was for an unspecified amount of cash and stock, to be in excess of $\$ 10$ million.

"This is what all of us want to see happen," McCorkle said. "This is a great deal for the state."

Officials at MesoFuel, when contacted by the Journal, declined comment, citing securities issues pertaining to Intelligent Energy's proposal to go public.

Intelligent Energy spokesman Mike Dunkley, reached by telephone, said the firm could not comment for the same reason.

The sale is a milestone for MesoFuel, which since 2001 has quietly been working to overcome one of the most vexing problems of the so-called hydrogen economy- how to reliably provide the hydrogen.

Fueling the industry

Put simply, hydrogen fuel cells work like a battery, in that a chemical reaction produces electricity. Because they emit no pollutant byproducts, hydrogen fuel cells have been widely touted as a potential alternative energy source that could eventually replace petroleum. 
President Bush last year pledged $\$ 1.2$ billion for fuel cell research over the next five years.

Potential uses for the technology range from stationary power generators for homes and businesses to replacements for some batteries on consumer electronics, and, eventually, automobiles.

But, though hydrogen is widely referred to as the most abundant element in the universe, the processes for stripping hydrogen from the compounds in which it is typically found have lessened its potential usefulness as a fuel.

Compounding that problem has been the issue of storing, shipping and distributing hydrogen.

MesoFuel CEO Ned Godshall, an accomplished entrepreneur and former Sandia National Laboratories scientist, has previously compared the fledgling industry to millions of cars driving around without any gas stations.

And that is where his company comes in.

It has developed a tiny, highly efficient device that renders hydrogen from commonly available liquid and gas hydrocarbon fuels, even gasoline. Such a device, attached to a fuel cell, can create hydrogen right where it's needed.

London purchaser

Launched in 2001, Intelligent Energy makes fuel cells ranging from small 10 watt devices to large systems capable of generating 25 kilowatts of electricity. Since its founding, the company has made several acquisitions in the United States and abroad, allowing it to offer a complete set of components that CEO Harry Bradbury told Fuel Cell Today magazine made the company a "complete energy solutions business."

Bradbury has said the firm plans to develop fuel cell technology, then license it to larger manufacturers.

"We are not setting ourselves up to manufacture," he recently told the Reuters news agency and several energy industry publications in a press release. "We are collecting blue-chip partners to develop pre-production prototypes to embed our 
technology into their products. The playground for us is in the development space for the big blue chips that are in this sector."

Raising capital

Intelligent Energy recently applied to trade on the Alternative Investment Market of the London Stock Exchange. It is expected that the firm will begin trading in June, and company officials have said it expects to raise more than 40 million pounds or about $\$ 71$ million.

In the six months ended in March, the company reported revenues of 1.38 million pounds, or $\$ 1.65$ million, according to Reuters. Intelligent Energy officials did not return calls and e-mails seeking comment.Intelligent Energy employs about 70 people. MesoFuel employs 14.

McCorkle said MesoFuel is expected to remain in Albuquerque and will likely grow.

"We should see jobs added over the next year," he said. MesoFuel spun out from Albuquerque air-sampling device developer MesoSystems.

At the time of its acquisition, it was in the middle of raising $\$ 4$ million in venture capital. McCorkle said the firm had to date raised about $\$ 1.7$ million from angel investors and Texas-based Murphree Venture Partners.

"If I was one of those angels or Murphree, I'd be extremely happy," he said.

Tom Stephenson, a local representative for Murphree Venture Partners, would not comment on whether the firm had been purchased. He did confirm he had resigned from his board position with MesoFuel and that fund-raising efforts had ceased.

"We remain very excited about the prospects for MesoFuel's technology and opportunities," he said.

MesoFuel also recently received a $\$ 2$ million grant from the National Institute of Standards and Technology for further development of its hydrogen generator systems. 
Final Technical Report

APPENDIX C 
Final Technical Report

Information:

March 1, 2004

Toni Balzano

505-843-4221/505-934-3127

\title{
For Immediate Release Enerpulse Inc. Receives \$2.25 Million In Venture Capital
}

\begin{abstract}
ALBUQUERQUE- Technology Ventures Corporation (TVC) is pleased to announce that Enerpulse, Inc. has received $\$ 2,250,000$ in venture capital funding from Altira. Altira is a Colorado based venture capital firm focused on energy technology. The equity financing will be used to fund testing and marketing of the PulStar spark plug.
\end{abstract}

Enerpulse has developed a unique and patented spark plug called PulStar. The PulStar spark plug can generate up to 10,000 times more spark power than a conventional spark plug. This low cost spark plug replacement can offer better fuel economy, increased performance and reduced emissions.

According to Enerpulse President and inventor Louis Camilli, "PulStar is the first real advancement in spark plug technology in decades. It could be the most cost effective solution available to automakers to meet new government fuel economy standards."

The PulStar technology has already been proven in a two-piece aftermarket version of the product. Over the past 5 years, Enerpulse has sold and installed 50,000 of these spark plugs for use in a variety of engines, from lawn mowers, to modern sport utility vehicles.

Enerpulse, Inc. is a privately held company with offices in Albuquerque and Orlando, Florida. The company was founded in 1996, to develop and market products based on pulse power. In January 2003, Enerpulse was chosen to present at Technology Ventures Corporation's $10^{\text {th }}$ Annual Equity Capital Symposium, held in May. TVC project manager Andrew Salazar said, "the speed at which this deal came together is a tribute to the strength of the Enerpulse management team." For more information about Enerpulse and their technology log on to www.directhits.com.

Altira is a seed and early stage venture capital firm focused on energy technology. Based in Denver, Colorado, the firm is investing from its fourth fund. The firm targets opportunities in the first institutional equity rounds with initial investments of $\$ 500,000$ to $\$ 3$ million. For more information on Altira see www.altiragroup.com

Technology Ventures Corporation helps entrepreneurs create technology companies and finds qualified investors to fund them. TVC is a non-profit foundation funded by Lockheed Martin Corporation and the National Nuclear Security Administration. It has offices in Albuquerque, Santa Fe, Los Alamos, New Mexico; Livermore, California, and Las Vegas, Nevada.

www.techventures.org 
Final Technical Report

\section{APPENDIX D}


New Mexico Business Weekly

November 14-20, 2003

EXCLUSIVE REPORTS

No longer missing: NM reappears on $\mathrm{VC}$ reports

Andrew Webb

NMBW Staff

Two quarterly surveys show New Mexico is back on the venture capital radar in a big way, though local insiders argue that the state never really dropped off.

The Money Tree Survey by Price WaterhouseCoopers, Thompson Venture Economics and the National Venture Capital Association reports

that New Mexico had about $\$ 3.2$ million in venture capital investment during the third quarter of 2003, if you subtract the $\$ 12$ million investment to a California firm that was erroneously included in New Mexico numbers. And the U.S. Venture Capital Funding report by Venice, Calif. market research firm Growthink Research reports more than $\$ 90$ million in funding received by New Mexico firms in the last quarter.

The Money Tree Survey included \$3 million to Albuquerque network security firm Seclarity, $\$ \mathbf{4 0 0 , 0 0 0}$ to photovoltaic cell manufacturer Advent Solar, and a \$150,000 follow-on investment to Albuquerquebased technology firm Quasar.

Growthink's figures included the funding to Seclarity and Advent Solar, as well as an $\mathbf{\$ 8 7}$ million Series $E$ round to Albuquerque jet plane developer Eclipse Aviation from the State Investment Council and other undisclosed investors.

Both surveys, which depend on voluntary reporting by venture capital firms, said there was no venture capital funding during the first and second quarters of 2003, though local records indicated several such deals did transpire. 
And, actually, the state had a handful of other investments during the third quarter that weren't noticed by the surveys, says Randy Wilson, director of business operations for Albuquerque-based Technology Ventures Corporation, a Lockheed-Martin-funded nonprofit that aims to hook tech firms up with investors and foster commercialization of technology from the state's labs and educational institutions.

However you look at it, things are looking better for New Mexico's small firms, he says.

"We've seen a lot of interest in New Mexico," he says. "It's very exciting."

He says the last three years have demonstrated "an upward curve" in venture investment.

About \$40 million was invested in New Mexico firms in 2002, and about \$23 million was invested in 2001.

"It's safe to say we'll have $\$ 35$ million by the end of this year in 15 or more deals," Wilson says.

According to TVC's figures, the third quarter saw about $\$ 5.3$ million in investment. Funding rounds apparently missed by the surveys included Albuquerque materials developer Surfect, which got about $\$ 385,000$, another photovoltaic cell developer, Solaria, which received $\$ 500,000$ and a company which develops systems to streamline alternative medicine claims processing, Alternative Link, which landed \$1 million.

Three more firms that have worked with TVC are close to a total of \$9 million in investments, which could close by the end of the year, Wilson says. Three firms received investments totaling $\$ 13.7$ million in the first two quarters of 2003, according to Wilson.

Wilson says he's glad some of the state's investments are starting to turn up again on national surveys. 
"It's encouraging that they're starting to learn about some of the venture investments in New Mexico and are including them in their reports," he says.

Nationwide, venture capital investments held stable. Investors put $\$ 4.2$ billion in 667 companies in the third quarter of 2003, according to the Money Tree report. Venture capital has hovered at around \$4 billion for the last five quarters, according to the report. Growthink reported similar figures.

Health care and telecommunications businesses took the bulk of the quarter's investments, according to both reports.

Nationwide, the industry has gone from a rate of $\$ 110$ billion invested per year in 2000 back to about \$15 to \$20 billion annually, says National Venture Capital Association Vice President of Research John Taylor.

"That lines up overall with where things were in 1997 and '98," he says. "Lots of folks who have been in business for a long time feel that's the right size for the industry."

George Friberg, TVC director of project development and business assistance says things are looking up.

"It's never going to be at the level we were before, but it's beginning to pick up steam," he says of national investing. "There's money out there that needs to be deployed."

awebb@bizjournals.com | 348-8324

(C) 2003 American City Business Journals Inc.

Web reprint information

All contents of this site (C) American City Business Journals Inc. All rights reserved. 


\section{VentureWire Exclusives}

back

\section{Photovoltaic Cell Firm Advent Solar Receives \$400K in Series A \\ By Jonathan Matsey \\ 10/31/2003}

Sandia Park, N.M. -- Advent Solar, a producer of photovoltaic cells, is closing $\$ 400,000$ in Series A financing, VentureWire has learned. The company is based in Sandia Park, N.M.

New investor Air Products and Chemicals led the round, joined by existing investor Angles with Attitude and other individual angels. Funding will help the company continue designing its prototype. Advent Solar is developing photovoltaic cells, modules, and integrated products based on solar power. The company's core technology is an emitter wrap-through design, which CEO Rusty Schmit said increases performance and decreases production costs. This process enables the company to develop ultra-thin silicon wafers, which it says will lower the price of solar power from the typical wholesale price of $\$ 3$ per peak watt to about $\$ 1$. Mr. Schmit previously served as CEO of Photowatt and in PVrelated managerial positions at Motorola and Texas Instruments. Advent Solar's technology came out of two decades of research at Sandia National Laboratories, according to vice president and CTO James Gee, who did much of that research at Sandia as a senior scientist. Advent Solar has an exclusive agreement with Sandia for this technology. As a result, he noted, with research and development behind them, the company is already at the prototype stage. The company also has an agreement with Georgia Tech to use their laboratories for research.

Mr. Schmit said the company is not planning on selling to end users and will contract instead with an OEM. Mr. Schmit sees many uses for Advent Solar's technology, including parking meters and certain features in automobiles.

Advent has also begun looking for a Series $B$ round of financing for about $\$ 7$ million, said Mr. Schmit. This money, which Advent Solar would like to raise by the end of 2004, will help the company get to pilot production. Advent Solar, founded in 2002, received seed funding in July from its founders and Angels with Attitude. The company has 
four employees, but Mr. Schmit said the company will have about 50 by the end of 2004 .

http://www.adventsolar.com 
Final Technical Report

APPENDIX E 
URL: http://www.albuquerquejournal.com/biz/116502outlook12-0103.htm

\author{
Albuquerque Journal \\ Monday, December 1, 2003 \\ Solar Startup Shines \\ By Aaron Baca \\ Journal Staff Writer
}

Advent Solar is a brand-new startup that doesn't even have an office yet. But apparently the Albuquerque company, which hopes to manufacture a new kind of solar cell, looks like a good investment.

Advent Solar won a \$7,000 cash prize and \$3,000 in business services last week after taking first prize in the National Clean Energy competition in Austin, Texas.

The prize comes after two successful rounds of funding for Advent. The company received an undisclosed amount of seed funding from angel investors in the summer. And more recently the company closed on a $\$ 400,000$ investment this month.

Now the company has its eyes on raising even more cash, roughly $\$ 6$ million to $\$ 8$ million, in the next year.

The competition in Austin was part of the three-day National Renewable Energy Laboratory Industry Growth Forum, which is meant to be a springboard for new energy companies looking to attract investors.

The award, while not materially significant, is meant to spotlight energy ideas and viable business plans, said Julie Brokaw, a spokeswoman for San Francisco-based Bechtel Corp., a founding sponsor of the forum. 
An impressive showing

"I think a lot of venture capitalists were impressed with Advent. They were really impressed with Rusty (Schmit)." Schmit is Advent's founder and CEO.

"I'd say we're off to a good start," Schmit said. "It was slow going at first. Things are definitely picking up now."

Schmit says Advent plans to move into an office in the Albuquerque Technology Incubator at the University of New Mexico's Science and Technology Corp. on Broadway SE.

If the company can raise more capital in the coming year, Advent plans to build a pilot production plant where it would build solar cells within two years.

Schmit says, however, he doesn't know if that plant would be located in Albuquerque.

A new solar cell

Advent was started in 2002 using technology licensed from Sandia National Laboratories. The company plans to manufacture a line of advanced photovoltaic cells that will be thinner and more efficient than current solar cells.

The solar cells Advent is working on are made on ultra-thin silicon wafers that the company believes will help reduce manufacturing costs.

Schmit says the thin solar cells are unusual in that they don't look like solar cells at all. Thanks to the thin silicon wafers on which the cells are manufactured, the cells can be made to look like decorative glass.

"The problem with solar modules (panels containing hundreds of solar cells) is that they're kind of ugly," Schmit said. "Ours look uniform in color. They're much less gaudy than traditional solar cells." Brokaw said Advent's business plan, and the Sandia-developed technology being pitched by the company, impressed investors at the 
Austin forum. That could be a plus for the company going forward, she said.

"Not all deals happen at the forum," Brokaw said. "What's important is that investors see the companies and are aware of them. That helps make a deal later on."

Of the 36 companies that made presentations at the Austin forum, seven were from New Mexico or had ties to New Mexico through Technology Ventures Corp.

In addition to Advent, other companies making presentations with local ties were MesoFuel, AFS Trinity Power, Weather Miser Energy Efficiency Company, Sacred Power Corp., the Solaria Corp. and Surfect Technologies.

Copyright 2003 Albuquerque Journal Click for commercial reprint permission (PRC\# 3.4676.116502)

All content copyright (C) ABQJournal.com and Albuquerque Journal and may not be republished without permission. Requests for permission to republish, or to copy and distribute must be obtained at the the Albuquerque Publishing Co. Library, 505-823-3492, or through Icopyright.com. 
New Mexico Business Weekly

\section{LATEST NEWS}

November 21, 2003

Advent Solar wins national award

NMBW Staff

A small Albuquerque-area firm engaged in the development of photovoltaic technology has won the 2003 National Clean Energy Venture

Competition at the National Renewable Energy Laboratory's 16th annual Industry Growth Forum.

Advent Solar beat 35 competitors to take the top prize, which includes $\$ 7,000$ in cash and $\$ 3,000$ worth of incubation services from the Austin Clean Energy Incubator. The competition was sponsored by Bechtel Corp.

Advent produces a line of solar cells based on technology developed at Sandia National Laboratories. The cells are cheaper to make, more efficient, and better looking than traditional technology, according to the firm.

"I'm pleased to win this award from Bechtel, and want to thank NREL for the opportunity to present to such an illustrious group of investors and colleagues," Advent CEO Rusty Schmit said in a release. "This validates Advent's business potential, its technology, and its team."

Participants in the competition were selected from hundreds of applicants to present their business plans to energy executives and other potential investors.

Schmit, who has developed solar energy technology for the labs and for private firms around the world, founded Advent a year ago. The firm recently received a $\$ 400,000$ seed investment from Seattle-based investment group Angels with Attitudes LLC. 
(C) 2003 American City Business Journals Inc.

Web reprint information

All contents of this site $\mathbb{C}$ American City Business Journals Inc. All rights reserved. 


\section{News from Bechtel}

For more information contact

Julie Brokaw

972-539-8680

jebrokaw@bechtel.com

\section{For Immediate Release}

\section{Bechtel Announces Winner of the 2003 National Clean Energy Venture Competition}

- Advent Solar, Inc Honored for Photovoltaic Technology

$-$

AUSTIN, Texas, November 19, 2003-A small company commercializing advanced photovoltaic technology has won the 2003 National Clean Energy Venture Competition at the $16^{\text {th }}$ NREL Industry Growth Forum.

Advent Solar, Inc., based in Albuquerque, New Mexico, beat out 35 competitors to take the top prize of $\$ 7,000$ plus incubation services from the Austin Clean Energy Incubator valued at more than $\$ 3,000$. Winners were announced Wednesday by Julie Brokaw of Bechtel Corporation, founding sponsor of the competition.

Advent Solar provides a full line of advanced photovoltaic cells and modules based on proprietary technology aimed at dramatically reducing the cost of producing electricity. Advent's technology is exclusively licensed from Sandia National Laboratories.

"I'm pleased to receive this award from Bechtel and want to thank NREL for the opportunity to present to such an illustrious group of investors and colleagues," said Rusty Schmit, president and chief executive officer of Advent. "This validates Advent's business potential, its technology, and its team." 
Participants in the competition were selected from hundreds of applicants to present their business plans to energy executives and other potential investors. Outstanding Presentation Awards of $\$ 1,500$ cash and $\$ 500$ in incubation services each went to ISE Corporation and Power Tube, Inc.

ISE, based in San Diego, California, is a leading supplier of hybrid-electric and fuel cell drive systems for heavy-duty vehicles such as buses and trucks. "Our ThunderVolt hybrid-electric drive systems and technologies are particularly exciting because of their potential to create a clean, efficient transportation system," said Michael C. Simon, CEO of ISE.

Power Tube is a Texas-based company developing novel technology for turning the heat of the Earth into electric power. "Its great to be recognized by the investment community for having a compelling clean energy business," said Power Tube CEO Glen Lovelace.

Bechtel provided $\$ 10,000$ to launch the annual clean energy award in partnership with the National Renewable Energy Laboratory (NREL), and the Austin Clean Energy Incubator. "As founding sponsor of this competition, Bechtel is proud to help showcase technological innovation and vision," said Brokaw, senior science and technology specialist at Bechtel. "It's exciting to get a sneak preview of our energy future. Society requires abundant and varied supplies of clean energy, and some really smart people are working very hard to meet that need."

Headquartered in San Francisco, Bechtel is a global engineering and construction organization, with 44,000 employees worldwide. 
Located in Golden, Colorado, NREL is a premier laboratory for renewable energy research. Its mission is to lead the United States toward a sustainable energy future by developing and employing renewable energy technologies and by improving energy efficiency.

The Clean Energy Incubator is a project of the Austin Technology Incubator at The IC2 Institute, The University of Texas at Austin. For more info contact cei@ati.utexas.edu or visit www.cleanenergyincubator.com.

Contact information for the winning companies Advent Solar, Inc., Rusty Schmit, President and CEO, Albuquerque, New Mexico, 505-281-1505,rschmit@adventsolar.com

ISE Corporation. Michael C. Simon, CEO, San Diego, California, 619-287-8785 Ext. 120, msimon@isecorp.com

Power Tube, Inc., Glen Lovelace, CEO, Austin, Texas 512-858-9410,glove@powertubeinc.com 
Final Technical Report

\section{APPENDIX F}




\section{Excerpt from Commercial Break \\ November 2003 \\ Publisher: Technology Ventures Corporation www.techventures.org}

\section{Clean Sweep at Clean Energy Forum}

Technology Ventures Corporation had seven companies present at a clean energy capital investment forum in Austin, TX on November 17-19, 2003, hosted by the National Renewable Energy Laboratory. The forum featured 35 competitors selected from over 100 applicants commercializing clean energy technologies. The seven TVC clients that presented were Advent Solar, AFS Trinity Power, MesoFuels, Sacred Power Corporation, The Solaria Corporation, Surfect Technologies, and Weather Miser Energy Efficiency Company. Another TVC client, Clear Skies Unlimited, was asked to present a poster paper at the conference. "We were delighted to have such a strong showing of TVC clients as presenters at the conference, and we feel very confident about their prospects for receiving funding," said Suzanne Roberts. Ms. Roberts is TVC's program manager for its NREL sponsored Clean Energy Incubator Alliance.

\section{Excerpt from Commercial Break February 2004 Publisher: Technology Ventures Corporation www.techventures.org}

\section{Cream of the Crop}

The 2004 New Mexico Equity Capital Symposium Presenters have been chosen. The 16 companies and their products are:

- Advent Solar; developing photovoltaic cells, modules and integrated products as the next generation solar power for utility grid-tied and small building interrogated systems.

- Centrisoft, Inc.; software that manages traffic-flow of information for organizations that are dependent on large networks.

- Evit Labs; has an FDA approved inhaler device used in the inhaled delivery of drugs, such as those drugs used to treat asthma.

- GET Systems, Inc.; developing specialized electroplating equipment for the electric component and medical device industries.

- Innovative Web Applications; designing collaborative software to aid in document management for large developers and users of complex policies, procedures and regulations.

- IO Star; developing a space transportation and recovery system to be used in outer orbit.

- Lifewave; developing portable non-invasive devices to be used to monitor patients with cardiopulmonary complications. 
- Logistics Vision; working on the development of a global tracking system to be used in commercial and government shipping.

- Maas Biolabs, Inc.; developing a drug to be used in the treatment of ALS, Alzheimer's and trauma patients.

- NanoEnergetic Materials; Working to create safer nano-based explosives such as electric matches, fuses and initiators.

- Pecos Labs, Inc.; developing an immunotherapeutic for use in disease control and biowarfare resistance.

- Progressive Language, Inc.; working on an on-line English as a second language immersion program.

- Retriever Technology; designing high quality digital imaging equipment for scientific applications.

- The Wind Turbine Company; developing a low cost wind turbine, to help encourage the cost effectiveness of wind farming.

- TwinACT, Inc; developing an interactive-media platform for on-line education and training, specifically aimed at consumer medical information.

- Weathermiser; an irrigation system that monitors climate conditions to help preserve water

\section{Excerpt from Commercial Break June 2004 Publisher: Technology Ventures Corporation www.techventures.org}

Vintage California

The presenting companies for TVC's $2^{\text {nd }}$ Annual California Equity Capital Symposium have been chosen! The 18 best business cases were selected out of over 100 submissions for the event held on September $16 \& 17,2004$. Here is the list of selected presenters:

AAE Systems, Inc provides communications via satellite for applications that include voice, fax, data, Internet, and video.

AFS Trinity Power uses advanced flywheel power systems to replace batteries for power management and energy storage.

$\underline{\text { Amonix }}$ develops high-performance solar cells and photovoltaic power systems that generate low cost clean electricity.

Clear Skies offers a catalytic converter that removes carbon monoxide, particulates, and volatile organic compounds from polluted air streams.

CommandCAD Inc provides electronic design automation (EDA) software to improve the manufacture of large-scale integrated circuits.

Designed Nanomaterials develops new composite engineering materials for sealants, adhesives, coatings, and electronic device packaging materials.

Fast Ditch uses recycled polyethylene material to line irrigation ditches and reline deteriorated concrete irrigation and drainage channels.

GluQuest develops barely invasive wireless and continuous glucose monitoring patches for diabetics. 
H2Onsite generates high purity hydrogen for small-volume industrial users, vehicle refueling centers, and stationary power applications.

Maas Biolab uses cyclosporin as a neuroprotectant in the treatment of neurodegenerative diseases such as ALS, Alzheimer's, and Parkinson's.

Nanosense Corporation develops nanotechnology-enabled biosensors for ultra-sensitive detection of biological and chemical agents.

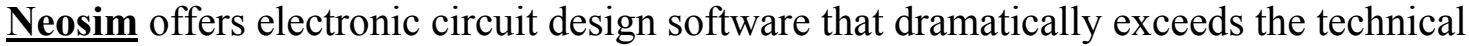
capabilities of current EDA simulation products.

Sensametrics provides wireless sensing units for real-time vulnerability/damage determination of civil assets and infrastructure.

Silicon Clocks incorporates timing devices directly into integrated circuits, dramatically lowering power consumption.

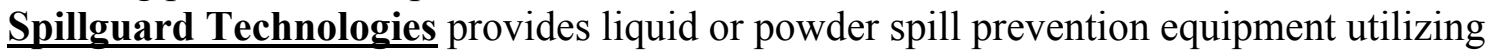
predictive intelligence to petroleum facilities.

Tailwind offers secure distribution and monitoring of vital, media-rich, Web-enabled content for mobile workers.

Vascular Biosciences provides an endoarterial catheter that allows better diagnosis and management of vascular-based diseases.

VitalWear automates contrast therapy thermal compression systems to accelerate recovery from a broad range of injuries and chronic conditions.

\section{Excerpt from Commercial Break October 2004 \\ Publisher: Technology Ventures Corporation www.techventures.org}

NREL Growth Forum that aims to finance the path to clean energy and a hydrogen future features two TVC clients

The $17^{\text {th }}$ National Renewable Energy Laboratory (NREL) Industry Growth Forum will be held in Orlando, Florida October 18-20, 2004. TVC, which is a member of NREL's National Alliance of Clean Energy Incubators, mentors two clients who have been accepted to present at the forum before an audience of venture capitalists that invest in clean energy and energy efficiency opportunities. The Wind Turbine Company seeks funding to commercialize wind turbines that will reduce the cost of wind-generated electricity by one third. Redwood Rubber, LLC, will use equity investment to inexpensively recycle used tires into devulcanized rubber and high quality molded consumer end products. Another TVC client, Zia Power, Inc., has been invited to the forum as an alternate. Zia Power seeks to offer intelligent solar solutions using state-ofthe-art manufacturing and cutting edge solar module designs. For more information, please go to www.cleanenergyforum.com or call TVC's Suzanne Roberts at 505.843.4091. 
Final Technical Report

\section{APPENDIX G}




\author{
For More Information, Contact \\ Suzanne Roberts 505.843.4091 \\ David Weinerth 925.960.1600 \\ Technology Ventures Corporation \\ For Immediate Release \\ November 14, 2003
}

\title{
TVC AWARDS \$10,000 ROADRUNNER GRANT TO AFS TRINITY POWER
}

\begin{abstract}
Albuquerque, New Mexico - Technology Ventures Corporation (TVC) announced today its award of a $\$ 10,000.00$ RoadRunner grant to AFS Trinity Power Corporation (AFST). Based in Livermore, California, AFST is launching the most significant development in UPS (uninterruptible power supply) and power quality since the rechargeable battery. The company has high potential to displace lead-acid batteries, a long-term environmental nuisance, in a number of industrial applications. Additionally, its focus on enabling battery-less hybrid vehicles and distributed power generation makes AFST appealing to clean energy advocates.

Motivating TVC's award to AFST were several factors. As a TVC client, the AFST supports a cooperative agreement between TVC and the National Nuclear Security Administration (NNSA). TVC's work with AFST contributes to the objective of commercializing technology from Lawrence Livermore National Laboratory (LLNL). AFST is a licensee of technology developed at LLNL.
\end{abstract}

Additionally, AFST supports TVC's participation in The National Alliance of Clean Energy Business Incubation. TVC's work with AFST contributes to the objective of accelerating the growth and success of clean-energy companies. With TVC's support, AFST was accepted to present at the $16^{\text {th }}$ NREL Industry Growth Forum in Austin, TX on Nov. $17^{\text {th }}$.

Finally, AFST demonstrates the potential to raise significant equity capital in multiple rounds ( $\$ 2, \$ 12$, and $\$ 20$ million, respectively) once it can provide working prototypes to channel partners. AFST has received two commitments from large UPS suppliers, as well as more than 100 qualified sales inquiries from potential end-users. Currently, the company is only months away from providing beta-level flywheel prototypes for customer evaluation. TVC's grant will sustain AFST's fundraising and business development efforts until it gains sufficient equity capital.

TVC in partnership with NNSA helps entrepreneurs create technology companies and finds qualified investors to fund them. It was founded in 1993 by Lockheed Martin Corporation as a tax-exempt, nonprofit foundation. It has offices in Albuquerque, Santa Fe, and Los Alamos, N.M.; Livermore, Calif.; and Las Vegas, Nev.

www.techventures.org 
Final Technical Report

APPENDIX H 
Final Technical Report

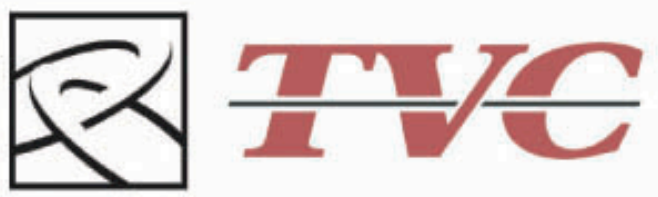

TECHNOLOGY VENTURES CORPORATION

Enabling Innovation - Accelerating Investment

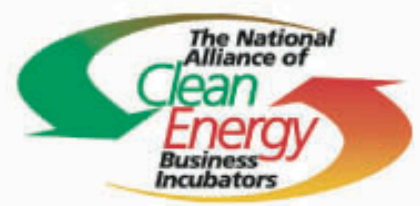

\section{Technology Ventures Corporation}

is a member of the National Alliance of Clean Energy Incubators which encourages the commercialization of clean energy technologies in New Mexico. TVC is a proud partner of the Sustain Taos initiative.

Technology Ventures Corporation is a non-profit that works to commercialize technologies and create jobs by helping entrepreneurs build business cases and find investors.

For information on our free services got to www.techventures.org, or call 505-246-2882

Funded by Lockheed Martin Corporation and the National Nuclear Security Administration 
Final Technical Report

\section{Technology Ventures Corporation: \\ "A Bridge between Clean Energy Entrepreneurs and Equity Investors" Published in the Sustain Taos Green Guide}

By Suzanne Roberts

October 18, 2004

Director, Project Development and Business Assistance

Technology Ventures Corporation

suzanne.s.roberts@1mco.com

Technology Ventures Corporation (TVC) is a non-profit organization that assists entrepreneurs who are intent upon scaling their businesses to new heights. Funded by the Lockheed Martin Company and the National Nuclear Security Administration, TVC helps entrepreneurs create technology companies and finds qualified investors to fund them.

In 2002, the National Renewable Energy Laboratory (NREL) in Golden, Colorado, invited TVC to join its National Alliance of Clean Energy Incubators that consists of a select group of 11 of the nation's top incubators in 9 states dedicated to providing business and financial services tailored to the needs of the clean energy and energy efficiency community.

The Alliance supports a broad portfolio of technologies including renewables, microturbines, fuel cells, power quality, energy efficiency, alternative fuels, energyrelated e-commerce and information technologies, hydro-electric, and transportation. The goal of the Alliance incubators is to help clean energy companies grow strong and provide business assistance services that allow them to develop competitive advantages over other clean energy start-ups.

Two years after joining the Alliance, TVC mentors over 30 clean energy clients from its sites in New Mexico, Nevada, and California. The clients employ 140 employees, have raised over $\$ 30 \mathrm{M}$ in capital, and generated more $\$ 5 \mathrm{M}$ in revenue.

TVC's clean energy and energy efficiency clients are diverse, as shown by the sampling below.

Advent Solar Inc., Albuquerque, NM, is a photovoltaic cell and module manufacturing that will target U.S. system integrators. It has an exclusive license to technologies from Sandia National Laboratories.

Clear Skies Unlimited Inc., Albuquerque and Cloudcroft, NM, manufactures and sells a catalytic combustor that eliminates emissions from wood burning stoves, fireplaces, restaurant grills, and oil refineries. 
Enerpulse, Inc., Albuquerque, NM, manufactures and sells a capacitive discharge ignition system that is built into the footprint of a conventional spark plug to reduce emissions and enhance engine performance.

FastDitch, Inc., Vallecitos, NM, produces and sells irrigation and erosion control ditches made from recyclable polyethylene lining that is cheaper, less damaging to install, and requires less maintenance.

Weathermiser, Inc., Albuquerque, NM, manufactures and sells an irrigation control device that dramatically conserves water.

The Wind Turbine Company, Bellevue, WA, seeks to relocate to New Mexico where it will manufacture and sell a new two-blade that costs less to manufacture and produces as much or more electricity than turbines currently in use.

TVC's success in identifying and nurturing so many clean energy companies in such a short time period clearly points to a growth industry for entrepreneurs. The deregulation and restructuring of the electric utility industry, coupled with growing environmental concerns, create unparalleled opportunities for new clean energy products, services, and technologies. Power providers, venture capital firms, and public dollars are being invested in emerging energy companies at an unprecedented rate. New Mexico, with its abundance of sun, wind, and biomass, is well positioned to benefit from the rising tide of clean energy technology commercialization. 
Final Technical Report

APPENDIX I 


\section{HyTeP - The Hydrogen Technology Partnership}

$\mathrm{HyTeP}$ is an alliance representing industry, business, research laboratories, universities, and government, working together to enhance the economic development of New Mexico and the nation through a cooperative focus on hydrogen and fuel cell research, development, demonstration, and commercialization. By building on the world-leading hydrogen and fuel cell R\&D performed at the state's national laboratories for more than 25 years, HyTeP aims to create a cluster of research, engineering, development, service, manufacturing, and business organizations that will make New Mexico the worldwide center for hydrogen and fuel cell development.

We believe that the task of developing the next generation of commercially-viable fuel cells and supporting hydrogen technologies is too large and too complex for any one company or organization to master. By working together we can help the United States maintain its current lead in this vital technology and ultimately reduce the nation's dependence on oil imports.

The members of HyTeP seek to reduce barriers to cooperation, to promote investment, to ensure continued funding and support for research currently underway at our research institutions, and to support the creation of a Fuel Cell National Resource Center at Los Alamos.

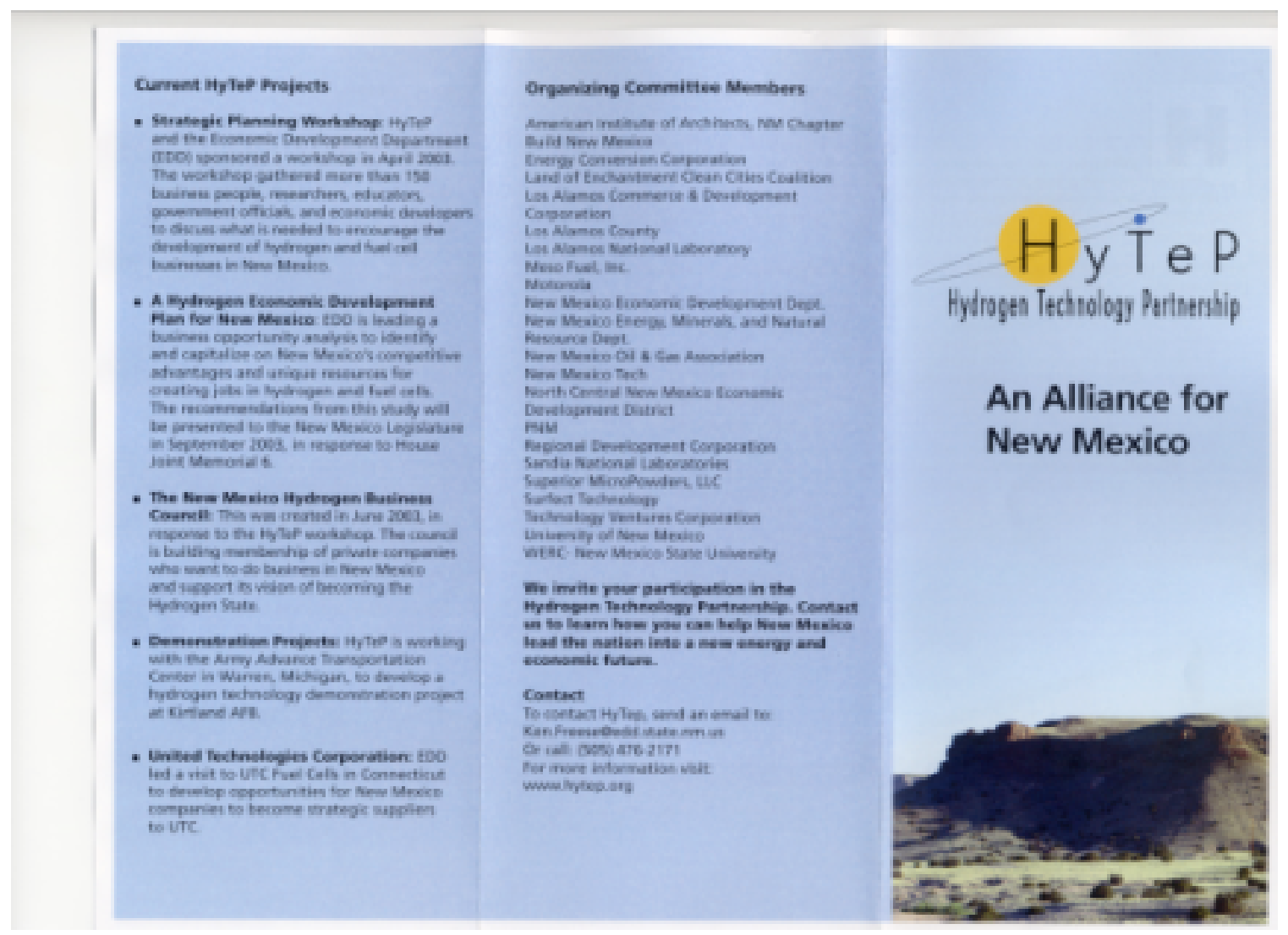




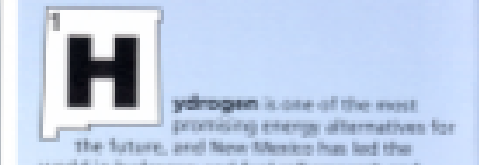

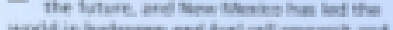

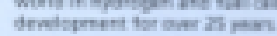

By Tea-The Hydregen levknolow Pertnershing

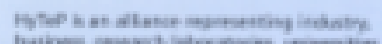

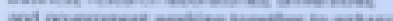

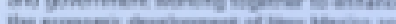

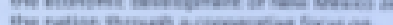

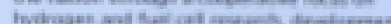

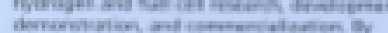

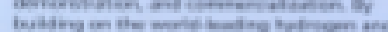

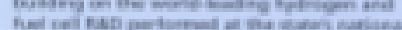

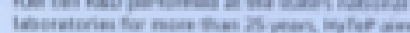

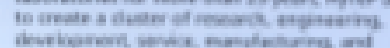

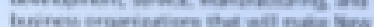

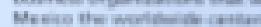
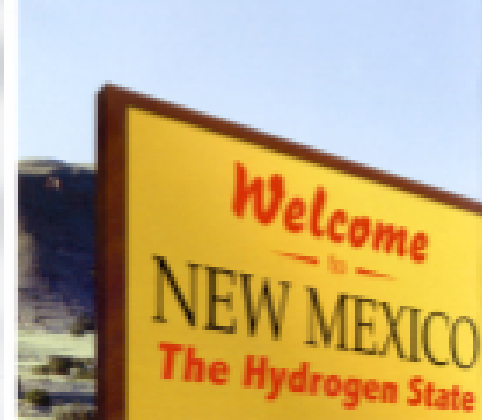

\section{Why Nere Maxice?}

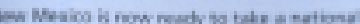

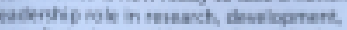
nerulationing, and kengrion of hydroges

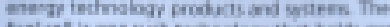

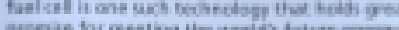

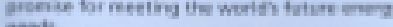

What does New Masics have to affer?

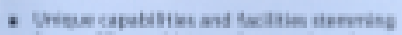

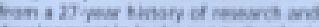
develapenent is frodoges teonedser

- Undus conthation of vience and engreerisgccospeteroes

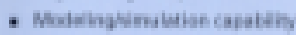

- Tenthesiere capdebly

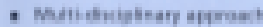

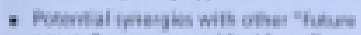

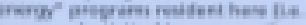

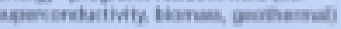

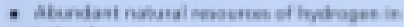
nuhid gan

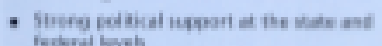

Hyteo is monking to

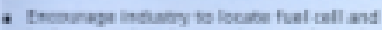
bedroper molined rasash maradectoring

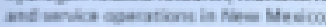

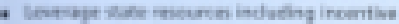

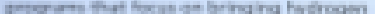

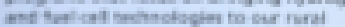
cannunkike

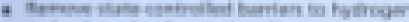

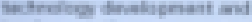
mulenasication

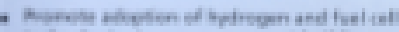

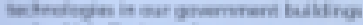

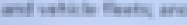

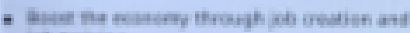
inemanis

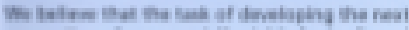

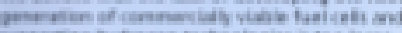

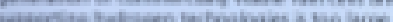

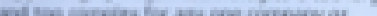

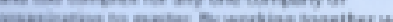

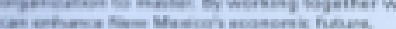

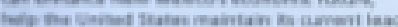

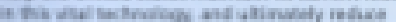

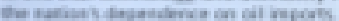


Final Technical Report

\section{APPENDIX J}


FPL Energy

October 1, 2003

Gov. Richardson joins FPL Energy and PNM to dedicate world's largest wind generation facility

Wind center will help area ranchers 'hang on' during drought years; FERC nominee Kelly, of Albuquerque, first resident to sign up for PNM Sky Blue

HOUSE, N.M. -- Gov. Bill Richardson and executives of FPL Energy and Public Service Co. of New Mexico (PNM) were joined by hundreds of business, environmental and community leaders today to dedicate the New Mexico Wind Energy Center, the world's third largest wind generation facility.

The wind center is located near House, N.M., which is home to 69 people.

The wind center captures eastern New Mexico's brisk winds to produce up to 204 megawatts (MW) of electricity, or enough to supply 94,000 average-sized homes. Unlike most power plants, it uses no water for energy production - an important feature in a drought-stricken state. FPL Energy, a subsidiary of FPL Group (NYSE: FPL), owns and operates the wind center; PNM, a subsidiary of PNM Resources (NYSE: PNM), purchases all of its output.

"I want our state to be a national leader when it comes to wind and solar energy," said Gov. Bill Richardson. "The New Mexico Wind Energy Center is a great first step toward fulfilling my goal to have 10 percent of New Mexico's energy come from renewable sources by $2010 . "$

Jim Robo, president of FPL Energy said, "The New Mexico Wind Energy Center is a prime example of a great project put together by a terrific team. Through hard work, dedication and teamwork, we have put together a project of which we can all be proud. We appreciate the support we have received in the area for our company 
and this project and are grateful for the commitment by our partners to wind energy."

"With this facility now operational, we have crossed a threshold from worthy goal to new reality in New Mexico," said Jeff Sterba, PNM chairman, president and CEO. "This is a living symbol of what can be accomplished when the public and private sectors work together to achieve sustainable economic prosperity."

The new facility catapults New Mexico to top-ten status among the 50 states for renewable energy production. It also allows PNM, the state's largest electric and gas utility, to begin offering renewable energy to its $\mathbf{3 8 5 , 0 0 0}$ electric customers for the first time.

Albuquerque lawyer Suedeen Kelly, a White House nominee to fill a vacant position on the Federal Energy Regulatory Commission

(FERC), today became the first PNM residential customer to subscribe to PNM Sky Blue, PNM's voluntary renewable program. The program begins today. Kelly was a commissioner on and chair of the state Public Service Commission, a predecessor organization to the state's current Public Regulation Commission, and currently practices law with Modrall, Sperling, Roehl, Harris \& Sisk, P.A., a New Mexico-based law firm.

Ranchers and environmentalists supporting renewable energy

The wind center will generate a local economic impact of more than $\$ 40$ million during the next 25 years through lease payments, salaries and payments to local school districts in lieu of taxes.

"This has been a wonderful shot in the arm for the community," said Renee Carter, whose cattle ranch plays host to six of the center's 136 wind turbines. "The droughts have really hurt the local ranchers and farmers, and this has given us a viable option to keep our homes and ranches."

"Agriculture is our bedrock business. Now the locals are able to hang on, in spite of the drought, and to look to the future," she said. 
The Coalition for Clean Affordable Energy (CCAE), New Mexico's largest energy-oriented consumer interest and environmental group, hails the new wind farm as a major step forward for New Mexico.

"This very serious wind power facility will displace half a million tons of carbon dioxide, a greenhouse gas and the main cause of global warming, use no water to do so, and will bring great benefits to our rural communities," said Ben Luce, CCAE chair. "We strongly encourage New Mexicans to support this project, and thereby help us expand renewable energy generation even further in New Mexico."

The wind center is located 20 miles northeast of Ft. Sumner. The turbines sit atop towers 210 feet tall and are powered by blades more than 110 feet in length.

FPL Energy is a leading unregulated wholesale generator of clean energy, including natural gas, wind, solar, hydroelectric and nuclear. It is the nation's leader in wind energy with 32 wind facilities in operation in 11 states. FPL Energy has a generating portfolio of more than 10,000 net megawatts in operation with more than 2,000 megawatts coming from clean and renewable wind energy. It is a subsidiary of FPL Group (NYSE:FPL), one of the nation's largest providers of electricity-related services with annual revenues of more than \$8 billion. FPL Group's principal subsidiary is Florida Power \& Light Company, one of the nation's largest electric utilities, serving more than 4 million customer accounts in Florida. Additional information is available on the Internet at www.FPLEnergy.com, www.FPLGroup.com and www.FPL.com.

PNM is the principal subsidiary of PNM Resources, an energy holding company based in Albuquerque. PNM provides natural gas service to 441,000 gas customers and electric utility service to 378,000 customers in New Mexico. The company also sells power on the wholesale market in the Western U.S. PNM Resources stock is traded primarily on the NYSE under the symbol PNM. For more information about our company, see our web site at PNM.com. 